\title{
A doutrina de combate da expansão imperial na cronística portuguesa da Terra de Santa Cruz
}

\author{
Wellington José Gomes Freire*
}

\section{Operações militares na América portuguesa quinhentista}

A ultrapassagem do cabo Bojador, feito que celebrizou o escudeiro Gil Eanes - e que abriu para ele o acesso às benesses reais da casa de Avis - descortinou uma via de acesso para três diferentes continentes: África, Ásia e América. Afastado o temor do mar ignoto e de todas as ameaças reais ou imaginárias que nele pululavam, as velozes embarcações portuguesas estabeleceram bases comerciais e pontos fortificados de defesa no magreb africano, nas costas da Guiné e no grande celeiro de produtos exóticos do Oriente. A joia da coroa, o grande sumidouro de homens e recursos bélicos do reino, foi o domínio das rotas de exploração marítima do continente asiático e das áreas litorâneas de importância estratégica. A América portuguesa, nesse contexto, de início, nada mais foi que teatro secundário, frente periférica de luta e de exploração. Front para o qual, inicialmente, se destinou uma quantidade menor de recursos por apresentar um caráter de zona não decisória de luta: a sua perda não representaria o comprometimento da capacidade ofensiva imperial lusitana. Às Índias, pelos dividendos econômicos que proporcionava, caberia a denominação acertada de schwerpunkt, ou eixo da ofensiva, de acordo com um dos célebres termos da doutrina militar germânica da primeira metade do século XX.

O Brasil se insere de forma quase acidental nesse processo de expansão imperialista, tendo resultado, como quer nos fazer crer uma bibliografia sobre o tema controvertido, de uma "barbeiragem" náutica do inepto comandante da frota destinada à Índia, o almirante Cabral. ${ }^{1}$ Se o avistamento das novas terras resultou ou não de conhecimento prévio anteriormente acumulado por secretas explorações cuja divulgação ficou recoberta pelo tão famoso quanto discutido "sigilo de Estado" de Jaime Cortesão é tema que aqui não cabe aprofundar. Para os fins das discussões que ora estabelecemos importa sublinhar que, ao contrário do que se passou no Oriente e no litoral africano, nenhuma grande formação de belonaves

" Doutor em Literatura pela Universidade Federal da Bahia, Salvador, BA, Brasil. E-mail: jutlandia1914@gmail.com.

Sobre as polêmicas envolvendo o "achamento" do Brasil e as diversas teorias há uma muito extensa bibliografia. Luís de Albuquerque (1992) no capítulo referente a Cabral oferece um panorama introdutório da questão. Veja-se também, Southey (2010 [1819]); Peres (1992); Cortesão (1992). 
transportando uma força militar invasora foi enviada a se assenhorear do novo território nas primeiras décadas de contato. E o motivo para isso não guarda grandes complexidades. Na Terra de Santa Cruz os invasores não se depararam com reinos opulentos que se estendessem por uma grande extensão territorial permeada por súditos que cultivassem as riquezas vegetais de tão grande valor de revenda na Europa. O nauta português não avistou grandes silos abarrotados de cravo, pimenta ou gengibre, muito menos teve a mesma oportunidade de se defrontar com cidades costeiras que eram ponto final de uma rica rede comercial que interligava o interior do continente com a zona costeira, como aquelas que Vasco Da Gama encontrou na África oriental islamizada.

A constatação inicial - que se revelaria equivocada - da inexistência de riquezas exploráveis, provavelmente contribuiu para o desinteresse manifestado pela possessão ultramarina recém reclamada. A frota de Cabral composta por 13 navios (10 naus e 3 caravelas) de grande porte era dotada de grande poderio militar, potencialmente impressionadora. Contudo, não deve ser esquecido que sua meta era impor autoridade sobre recantos insubmissos das paragens orientais em geral, e ao Samorim de Calicute, em particular. Uma força expedicionária invasora, ao estilo daquelas tantas que povoam as narrativas dos cronistas dos feitos praticados pelos portugueses na Ásia, com a função de transportar uma autoridade que atuaria como vice-rei imperial somente teria lugar na América portuguesa quase cinco décadas após o desembarque inicial de Cabral e seus homens. Claro está que no interregno entre os dois desembarques outras operações foram levadas a termo, algumas delas envolvendo número consistente de tropas embarcadas nas naus de combate. A possessão ultramarina não ficou de todo esquecida, mas os esforços empreendidos para ocupá-la - e aqui este termo deve ser entendido na sua acepção militar não foram da mesma monta, nem mesmo remotamente, daqueles empregados no esforço de guerra oriental, que era nos dias de então o front principal da luta.

Sendo um teatro de guerra secundário, um mero flanco de apoio do esforço ofensivo central, para ele recursos menores deveriam ser forçosamente direcionados de acordo com o princípio de que quando se luta em mais de uma frente, deve-se atacar o mais poderoso e apenas conter o avanço do mais frágil. Se o desembarque de Cabral não foi necessariamente uma operação de guerra, outras expedições que se seguiram adotaram padrões de combate mais claramente discerníveis. Mesmo sendo uma zona periférica da expansão imperial portuguesa - nas décadas iniciais do quinhentismo, entenda-se - foi necessário mantê-la, seja no sentido de uma diminuta presença em solo, seja no sentido de uma contenção de metas cobiçosas de potenciais navais de procedência europeia. Desse planejamento resultaram uma série de consequências, dentre as quais cumpre destacar as operações de patrulhamento costeiro e as tentativas infrutíferas de ocupação da terra sob forma de um sistema de arrendamento quase feudal.

A experiência militar portuguesa na América não se deu senão após quase um século de prática combativa e aclimatação nos trópicos. Uma força expedicionária 
duramente experimentada numa série de pugnas sangrentas contra combatentes africanos e asiáticos teve oportunidade de medir forças num novo ambiente de guerra ao qual também se adaptaria com surpreendente rapidez. Guerra de conquista e extermínio. Nova modalidade de luta esta, de todo condizente com as novas condições encontradas pelo invasor na zona de combate tropical. As incursões típicas da luta em África e na Ásia foram substituídas por uma nova mentalidade militar centrada na ideia de aquisição territorial a partir da expulsão dos habitantes originais das terras e de sua incorporação a um patrimônio imperial ultramarino. $\mathrm{O}$ antigo conceito posto em prática no Oriente, o de travar contato com o inimigo, desbaratá-lo e se retirar em seguida para a segurança de uma retaguarda solidamente guarnecida, foi substituído pelo deslocamento de forças que exterminassem o inimigo, fisicamente falando.

Novas condições de combate, nova doutrina de guerra - ou ao menos de uso da infantaria - mas um adversário que adotava normas de conduta militar em tudo semelhante aos já encontrados pelos nautas imperiais desde a operação de desembarque em Ceuta. Um novo inimigo que adotava princípios normativos largamente familiares aos lusitanos; vinhos velhos em odres novas. O sistema de conquista adotado no continente a ser incorporado ao patrimônio imperial ultramarino da Casa de Avis elegeu como princípio norteador incursões limitadas e localizadas e, por vezes, uma espécie de sistema hibrido de ação militar que permitia a utilização da força armada por pequenos grupos de pioneiros civis. Milícias exerceram nas décadas iniciais da conquista a função de ponta de lança de ofensiva que almejava o aprisionamento ou extermínio dos variados grupos tribais que habitavam na terra invadida.

O sistema de entradas, as expedições organizadas por sertanistas que devassaram o interior da grande província transoceânica, operou - talvez sem que sua intenção inicial tenha sido esta - de modo a produzir aquilo que séculos depois seria conhecido como limpeza étnica. As guerras balcânicas posteriores à queda do muro de Berlim ensinaram ao mundo - e não apenas ao restrito universo de estudiosos de história militar - o real significado desta expressão.

As condições peculiares do processo colonizador exigiram de parcelas significativas de civis como força de combate permanentemente mobilizada contra o inimigo, o senhor original das terras pilhadas pela sanha do invasor. Dos sertanistas aos membros de expedições exploratórias organizadas por particulares, passando pelos contemplados com as capitanias hereditárias, dentre os quais se incluiu um João de Barros com sua infrutífera experiência colonial, ${ }^{2}$ o poder real fez valer sua autoridade sobre grupos de colonos e os mobilizou para a guerra, ou para as guer-

2 O cronista João de Barros foi contemplado com uma capitania e devido à escassez de recursos financeiros ele dividiu seus custos de exploração com Aires da Cunha. A frota enviada ao Brasil era uma magnitude militar até então jamais vista na possessão ultramarina. Incluía 900 homens de armas e 100 combatentes montados. O que fez supor a muitos historiadores que as reais intenções eram outras, possivelmente atacar as cercanias do império Inca. Um naufrágio pôs fim ao empreendimento e resultou na morte de Cunha e mais dois filhos de Barros além da quase 
ras, visto que foram muitas e das mais variadas matizes. Abrangendo lutas localizadas e massacres hediondos praticados pelos dois lados envolvidos. A brutalidade esteve no cerne da doutrina de ambos os contendores. Os anos iniciais parecem ter sido de isolamento para os escassos núcleos de povoadores pioneiros que poucas comunicações mantinham entre si, dadas as distâncias quase invencíveis a separá-los. Pontos de defesa e ataque desvinculados de uma estratégia ampla e de apoio de forças de cobertura em terra ou no mar.

Na América portuguesa, diferentemente da experiência de guerra asiática não houve a coordenação orquestrada (ou quase) que caracterizou as ofensivas de tropas portuguesas. Em solo da província de Santa Cruz - futuramente solo brasileiro - a infantaria foi a mãe solitária de todas as batalhas. E essa glória ela não dividiria - como ocorreu no Oriente - com a marinha e com o apoio decisivo de uma retaguarda que se impunha pelo troar de uma ruidosa, e mortífera, baforada de metralha. Belonaves pairaram ao largo; transportaram tropas e colonos; deram combate a formações náuticas de potências inimigas de procedência europeia e em alguns casos pouco frequentes bombardearam formações inimigas em solo. Via de regra, contudo, sua função foi aquela que tradicionalmente lhe é precípua: a saber, esmagar o poderio naval inimigo.

Modalidade de guerrear que recorria ao uso de praças-fortes instalados nas faixas litorâneas como que a demarcar a presença do invasor. Seus canhões se encontravam apontados para o oceano, de onde, temia-se, surgissem as ameaças mais consistentes ao precário sistema defensivo erguido em praias hostis. E que eram duplamente hostis: do interior do continente também poderiam irromper subitamente hostes de formações adversárias prontas para fazer valer suas reivindicações de propriedade ancestral sobre a terra alvo das sangrentas disputas. Recorriam os lusos ao sistema de instalação de pontos fortificados de comércio, as feitorias de tão longa história militar na colônia. Os pequenos vilarejos, quase aldeamentos, erguidos junto às franjas litorâneas por pioneiros4Dos quais um modelo quase arquetípico foi o de Francisco Pereira Coutinho, apelidado, não sem razão, de Rusticão. Seu núcleo urbano erguido na região que hoje corresponde ao Farol da Barra era conhecido como Vila do Pereira e foi inteiramente destruída por uma incursão de índios aldeados na região. Para interessados num aprofundamento do tema recomenda-se Varnhagen (1979 [1854]); Sampaio (1949) Azevedo (1949); Carneiro (1985); Frota (2000.); Holanda (2007).

pecavam pela fragilidade defensiva que os tornava, como de fato aconteceu inúmeras vezes, alvo de incursões devastadoras dos aborígenes locais que se lançavam sobre os pontos de habitação provisória dos invasores. Renhidas batalhas, que serão alvo de análise mais detida em páginas seguintes, algumas celebrizadas nos compêndios de história colonial, outras obscuras, de repercussão limitada e conhecidas essencialmente por restrito número de especialistas. Via de regra, lu-

totalidade da tripulação. O cronista faz uma melancólica referência a isso nas suas Décadas. Para maiores detalhes ver o relato quase romanesco de Southey (2010 [1819]; além de Frota (2000). 
tas travadas sob o estigma da impiedade. Os relatos não deixam margem para dúvidas a esse respeito: uma guerra total conduzida até o fim sem considerações de ordem humanitária por ambos os lados envolvidos na contenda.

No primeiro século da conquista portuguesa da província recém reclamada, o quadro militar a ser esboçado oscilou num movimento pendular de defesa para repelir ameaças náuticas e de ataques formulados para o desbaratamento do poder militar dos habitantes originais da terra alvo da pilhagem. As circunstâncias de combate que se desenrolaram estiveram mais próximas daquilo que se assistiu nas incursões das praças-fortes africanas quatrocentistas e quinhentistas que da condução da guerra na Ásia. Dado que os muitos grupos inimigos encontrados na Terra de Santa Cruz se encontravam dispersos por extensa circunscrição territorial, não era possível realização de batalhas ao estilo convencional. Taticamente falando, a predominância deveria recair sobre incursões ligeiras que confiavam soberanamente na cautela, surpresa e violência no desencadear do golpe coletivo; estrategicamente falando, confiava-se num sistema que poderia ser apropriadamente descrito como de caça e aniquilação. Houve uma evidente predominância de batalhas terrestre e ofensivas ao estilo de agressiva incursão e saque. No mar, os confrontos foram travados exclusivamente contra belonaves europeias, visto que o indígena não possuía marinha de guerra ou qualquer coisa que a ela se assemelhasse.

\section{A cronística portuguesa quinhentista e a guerra}

Para estudo dos feitos militares lusos na América portuguesa não se encontra o auxílio de um Fernão Lopes de Castanheda (1500-1559) ou um Gaspar Correia (1492-1561). Por motivos que permanecem obscuros, parece não ter existido interesse pela redação de uma crônica abrangente e ambiciosa ao estilo daquelas que encontramos sobre a guerra de conquista das paragens do Oriente rico de especiarias. Talvez a razão disso se prenda ao brilho excessivo das riquezas orientais que ofuscavam os demais teatros da grande guerra de expansão imperial, desestimulando o interesse pela formulação de uma narrativa de amplitude. Inexistindo uma sistematização de certa confiabilidade da qual possa se valer, resta a todos aqueles que interessam por incursionar por este tema o recurso à utilização de uma gama variada de referências documentais dispersas e ao auxílio indispensável de um cotejo com fontes cronísticas quinhentistas. Um pormenorizado relato militar que que forneça uma visão geral da campanha na nova província ultramarina no período quinhentista, de fato, não há, muito menos qualquer narrativa que a isto se assemelhe. O número de aventureiros, soldados da fortuna e clérigos letrados enviados às novas paragens foi considerável, apesar disso nenhum deles se arvorou às pretensões de tornar-se um cronista-mor dos feitos de armas dos portugueses na América.

A obra de Pero de Magalhães Gandavo (1540-158o) (1964 [1576]) muito pouco - quase nada - acrescenta ao estudo de história militar do período que nos interessa. Apesar de nas páginas de abertura tratar de como se deu a colonização 
inicial, tudo isso é feito de forma demasiadamente aligeirada. Há referências genéricas à conquista das terras arrancadas ao gentio, sem considerações de maior extensão ou aprofundamento. Quais as circunstâncias de campanha? Onde se deram as batalhas? E sua natureza tático-estratégica? Acerca destes e de outros temas nenhuma palavra. A quase totalidade dos capítulos versam sobre uma louvação propagandística dos supostos benefícios proporcionados pela nova terra para futuros interessados na sua colonização. Discorre sobre aspectos etnográficos com as previsíveis considerações condenatórias à selvageria dos habitantes originais da terra; trata de questões botânicas e faz um breve sumário de novas espécies avistadas. É um relato de curta extensão e de limitada ambição histórica. Quase na mesma linha se insere a produção do padre Fernão Cardim (1939 [1580]). Apresenta maior interesse e revela detalhes de interesse mais imediato, embora a maior parte do seu livro revele a mesma preocupação do anteriormente citado, ou seja, a de se deter sobre temática etno-botânica.

Atenção mais detida mereceram no presente estudo as produções de Frei Vicente de Salvador e de Gabriel Soares de Souza (1540-1591). Do primeiro, douto clérigo dotado de apurado senso de observação, nos foi legada uma obra historiográfica - a primeira que se fez no Brasil - que embora publicada no início do século XVII aqui será utilizada como fonte por tratar do período quinhentista na maior parte de seus capítulos. Narrativa extensa e abrangente, cobrindo desde os temas já tratados por seus antecessores acima mencionados e incluindo outros tantos de maior amplitude. Trata-se de uma visão abrangente do primeiro século da colonização da Terra de Santa Cruz e de alguns de seus aspectos militares. Embora contendo lacunas no que se refere às duas décadas iniciais da presença lusitana na nova possessão ultramarina, a História do Brasil (1979 [1627]) fornece um valioso somatório de informações, algumas delas quase pormenorizadas, sobre ações de luta pela posse da América portuguesa.

Conhecidíssimo é o relato do intrépido aventureiro que encontrou um trágico fim no interior da Bahia quinhentista em demanda de míticas e fabulosas riquezas, entre as quais se incluíam uma lagoa de onde brotavam diamantes, a lagoa de Sabarabuçu. ${ }^{3}$ Gabriel Soares de Souza, pois é dele que falamos, foi um típico homem da renascença, condensava em si duas grandes matrizes de incentivo à ação dos homens de então: a cobiça mais desregrada aliada a uma curiosidade que parecia insaciável. Da primeira resultou seu trágico fim, supõe-se, flechado por índios paiaiás, na área que atualmente corresponde ao munícipio de Morro do Chapéu, interior da Bahia; ${ }^{4}$ do segundo resultou uma obra escrita que o imortalizou: O Tratado Descritivo do Brasil (200o [1587]), do qual nos valemos para a elaboração das discussões que se seguem neste texto.

\footnotetext{
3 Sobre mitos da conquista nenhum guia é mais indicado que o clássico estudo de Sérgio Buarque de Holanda (2007). Em complemento, em se tratando de informações sobre entradas ao estilo da de Gabriel Soares de Souza ver Tavares (2011); Sampaio (1949) Campos (2006).

4 Sobre circunstâncias de morte de Gabriel Soares de Souza e demais dados suplementares sobre seu périplo aventuroso veja-se: Tavares (2011); Salvador (1979 [1627]).
} 


\section{A Conquista da Terra de Santa Cruz: uma doutrina de defesa móvel}

O primeiro encontro entre as duas forças oponentes que se digladiariam futuramente de modo impiedoso até a quase extinção de uma delas, se deu de modo quase farsesco. Uma testemunha ocular nos deixou um relato do ocorrido e dele iremos nos valer. Antecedendo ao desembarque em terra de Pedro Álvares Cabral, um batel - veículo náutico de pequeno porte - foi lançado para contatar os habitantes locais que se encontravam amontoados junto à praia. Liderados por $\mathrm{Ni}$ colau Coelho, um número reduzido de nautas se aventura em direção aos recém avistados. O comandante os convida a entrar na embarcação e a depor sobre o assoalho as armas que portavam. Que cena nada impressionante para soldados experimentados nas lides da guerra do oriente: oito guerreiros habitantes do território que se pretende pilhar depondo mansamente seu armamento individual a um simples aceno de comando. A cena que se concluiu com o primeiro escambo realizado entre os representantes de dois mundos que em breve entrariam em choque armado foi bem pouco deslumbrante: colares de penas coloridos trocados por peças de tecido. Uma troca de bugigangas põe fim ao primeiro encontro entre os atores do drama fatídico a ser representado (CAMINHA, [1500], 200o).

O trato entre os representantes dos dois mundos pode ter sido quase farsescamente cordial no seu momento inaugural, mas rapidamente evoluiu para uma desconfiança e inimizade mútua que costumeiramente degenerava em confronto aberto. Os motivos para o irromper de ações violentas foram os mais variados, alguns justificáveis - como tentativas de escravização ou massacre de inocentes -, outros quase grotescos, como uma rixa nascida após uma briga de bêbados que redundou em trágicas consequências para um grupo de pioneiros povoadores, conforme se lê no relato de Frei Vicente de Salvador (1979, [1627]). Tendo causas justas ou não, todos os confrontos foram travados sob o estigma da impiedade. Uma guerra total levada às últimas consequências e que costumeiramente se concluía apenas com a aniquilação física das forças oponentes. Da validade disto nos afiançam relatos dos cronistas quinhentistas e leitura de fontes interpretativas contemporâneas, dentre as quais John Hemming (2007) é uma das mais recomendadas.

Guerra descontínua em termos das operações militares, mas continuada no que se refere à sua extensão temporal. Na ausência de cláusulas regulamentares ou de acordos tácitos que funcionassem como balizas demarcadoras de extensão de danos materiais, as ações de combate não se encerravam com a assinatura de termos de um armistício que pusesse fim às hostilidades. Inexistindo a possibilidade de assestar sobre o inimigo um golpe decisivo - dada a limitação de poder material ofensivo - o estado de aberta hostilidade se prolongava por tempo indeterminado. Uma batalha, ainda que prolongada, não definia os rumos de nenhuma das muitas campanhas que se desenrolavam em pontos isolados do interior ou da zona litorânea. Uma batalha decisiva, potencialmente aniquiladora, em termos definitivos, das pretensões ofensivas de qualquer um dos grupos envolvidos na contenda não poderia se desenrolar - como, de fato, não aconteceu em momento algum - 
devido aos precários meios disponíveis e a extensão da frente de combate, demasiadamente extensa.

No primeiro século de sua presença, a força invasora teve poder ofensivo suficiente apenas para firmar estreitas cabeças-de-ponte que se estendiam do Rio da Prata - na ponta sul de seu desenho ofensivo - até as proximidades da atual Pernambuco. Frente ampla, dispersa e desprovida de profundidade. Com exceção de umas poucas cunhas ofensivas, bolsões quase isolados em território hostil, o interior permaneceu sob controle inimigo que dele fazia uso para ações de ataque e de recuo tático que em muito dificultavam as pretensões dos portugueses. Escassos e pouco apetrechados - militarmente falando - sistemas de defesa fixa fundados sobre baluartes foram erguidos no litoral ou em áreas limítrofes. Funcionavam como ponto de apoio de retaguarda e como zona de recuo a ser utilizada em caso de desbaratamento de dispositivo ofensivo, o que aconteceu vezes sem conta. O poder militar invasor contava basicamente com uma infantaria indisciplinada desprovida de maiores meios de apoio de cobertura de avanço ou retirada. A cavalaria foi utilizada em circunstâncias isoladas e de forma não-convencional devido ao reduzido número de tropas montadas disponíveis para qualquer operação.

A modalidade de conquista adotada para a nova possessão divergiu em termos de condução tática daquela posta em prática no oriente e mesmo em África. No continente negro as operações se voltaram para a conquista de praças-fortes arrebatadas ao inimigo e que deveriam funcionar como cobertura de retaguarda de incursões comerciais com as zonas de interior. Predominaram, dessa forma, os desembarques anfíbios de tropas em larga escala e direcionadas para pontos específicos da costa inimiga. Conquistada a fortaleza-alvo os incursores tratavam de garantir um perímetro defensivo que desestimulasse ações de contra-ataque adversário. A posse do ponto de defesa encravado em solo inimigo não se articulava com concepções de posterior ocupação territorial. Princípios similares a estes foram executadas no Oriente, mas com particularidades próprias ao novo ambiente. Em se tratando de ofensivas que se desdobravam a milhares de quilômetros das bases de retaguarda, a mentalidade militar dominante era naval. O centro do dispositivo repousava sobre descidas em praias hostis com o fim de debelar forças inimigas que se concentravam em áreas próximas ao litoral. Combates de baixa intensidade e de curta extensão, com raras exceções a serem assinaladas.

O mais importante elemento tático herdado da campanha oriental utilizado na América portuguesa foi o da mobilidade tática absoluta. A natureza do inimigo - dado a ações de combate ao estilo insurrecional - desestimulava o emprego de concentração de forças. Não havia front estático no sentido tradicional. Em virtude disso, batalhas de choque eram amplamente desaconselháveis. A adaptação às condições locais de confronto exigia fluidez ofensiva e deslocamento constante como o dogma ofensivo. Os habitantes originais da terra invadida eram desde séculos praticantes de uma modalidade de guerra que desconhecia linhas inertes de defesa. Mesmo desconhecendo o uso de cavalos ou de qualquer outro animal de 
tração como instrumento de transporte e ruptura do ordenamento adversário, realizavam, desde tempos anteriores à chegada de europeus, uma guerra de movimento. Disso se infere que batalhas de atrito ou de usura foram modalidades raramente postas em uso, salvo em algumas circunstâncias excepcionais que teremos oportunidade de assinar no decorrer da discussão que ora realizamos.

No Oriente, os portugueses fizeram uso de uma doutrina de guerra naval e terrestre que utilizava o oceano como grande corredor de tráfego que interligava pontos distintos. Desse modo nenhuma zona inimiga estava à salvo de incursões predatórias e desembarques em larga ou pequena escala nas suas praias. Operando com velocidade, surpresa e ímpeto agressivo foi possível desalojar grupos nativos e se assenhorear de suas riquezas custosamente armazenadas. Fogo e movimento unido ao seu principal ingrediente - o ímpeto combativo de cada guerreiro animado de uma ideologia cavaleiresca - proporcionaram exitosos resultados. $\mathrm{Na}$ América portuguesa, contudo, as condições específicas de guerra reclamaram o uso da mobilidade absoluta acrescida de adaptações locais. Sem cobertura de fogo de artilharia naval - tão comum nas operações orientais e escassamente utilizado na nova possessão - as ofensivas se tornaram restritas em termos de poder de penetração. As armas de fogo portáteis e os instrumentos perfurantes e cortantes eram por si só incapazes de fornecer a superioridade necessária a um avanço de grande monta, mesmo em se tratando de adversário que lutava fazendo uso de armas de arremesso sem significativo alcance.

Sem os poderosos canhões de cobertura de retaguarda, as ações ofensivas se concentravam sobre incursões lançadas sobre as posições desguarnecidas do inimigo, quase sempre contando-se com o vital elemento surpresa. Frei Vicente de Salvador (1979 [1627]) nos fornece algumas referências a combates dessa natureza. Aldeamentos indígenas sendo metodicamente destruídos por ofensivas ao estilo de "limpeza de terreno", como se diria na moderna nomenclatura militar, são facilmente encontráveis na crônica anteriormente citada. Nessas operações, vê-se com clareza os métodos de ação direta empregados pelos invasores. Ataques em colunas independentes - nos mesmos moldes daqueles que foram tantas vezes utilizados no Oriente, conforme já foi possível notar após contato com os cronistas do Oriente português - incidiam sobre a área alvo, se acercando e lançando sobre ela uma borrasca de fogo e chumbo.

Para além das sutis diferenças, as semelhanças uniam as concepções táticas utilizadas no Oriente e na América portuguesa. Em ambos os teatros de operação uma força anfíbia combate sob os ditames de limitações operacionais: sem bases de apoio; com comunicações deficientes; com improviso tático; e sem organização militar que permitisse classifica-los como algo parecido com um "exército moderno". Na nova possessão ultramarina muito mais do que noutras plagas orientais, o elemento decisivo das incursões foi o fator moral a favor dos invasores, o furor possesso tipicamente integrado à uma mentalidade cavaleiresca medieval. Destituídos de uma força armada institucional, mas dotados de uma capacidade 
ofensiva que os fazia ombrear com a ferocidade dos habitantes originais da terra e de seus singulares métodos de condução da guerra.

Se no front oriental da guerra imperial intercontinental portuguesa havia a prática do envio anual de frotas de combate com a dupla missão de alargamento da conquista e de cobertura das forças instaladas em terra, ${ }^{5}$ o mesmo princípio normativo não foi extensivo às operações na América portuguesa quinhentista. A etapa inicial da tentativa de submissão das populações nativas com consequente apropriação de suas terras ficou sob responsabilidade - nas suas linhas gerais - da iniciativa de grupos isolados de pioneiros. Os núcleos de povoamento por eles erguidos em diferentes pontos da costa embora interligados por uma precária linha de comunicação terrestre e marítima, se encontravam militarmente desvinculados. Nenhum tipo de concepção estratégica unia esses pontos dispersos. Muito menos existia algo que se assemelhasse ao sistema espanhol de conquista colonial. As cabeças-de-ponte fincadas em solo, não visavam um objetivo militar previamente definido, como acontecia no caso dos espanhóis que lançaram diferentes expedições em pontos distintos do litoral americano, mas sempre visando uma meta especifica. ${ }^{6}$ Nas primeiras décadas os portugueses puderam apenas arranhar o litoral - ou uma pequena parte dele. Não se deve esquecer que de Pernambuco ao Amazonas praticamente inexistiram operações militares quinhentistas. ${ }^{7}$

Como lutaram as forças portuguesas instaladas na Terra de Santa Cruz? Primordialmente deve ficar claro que a doutrina militar adotada durante a expansão imperial desde Ceuta foi a mesma, apresentando variações e acréscimos que se adaptavam à realidade local de circunstâncias geográficas diferenciadas. Diz Gilberto Freyre (2004) que o português enquanto conquistador militar moderno apresentase como uma pálida figura. Destituída de um traço forte que o individualize ele se assemelharia a uma junção de dois modelos imperialistas: o inglês e o espanhol, mas sem que nenhum dos traços predominasse. Criatura hibrida e quase camaleônica na formulação de uma doutrina militar ofensiva de conquista imperial. Desajustado em termos dos cânones contemporâneos de guerrear, fiava-se basicamente na independência de ação do combatente de base. A mentalidade ainda fidalga no que se referia aos modos de condução da guerra não se assentava numa

5 Acerca desse ponto ver as muitas referências que constam nos cronistas das paragens do Oriente: Castanheda; Correia; Couto; Barros; veja-se ainda historiadores dos descobrimentos, Godinnho (1990); Peres (1992); e principalmente Albuquerque (1992). Castanheda mostra-se mais minucioso, acompanha todas as frotas enviadas desde 1500 a 1550 , data limite da cobertura de seu texto cronistico.

6 Uma análise comparativa entre as duas conquistas imperiais, a espanhola e a portuguesa é tema que reclama um desenvolvimento mais aprofundado que aqui não seria possível realizar. Acerca das operações de incursão das forças espanholas em território americano veja-se Bernard e Gruzinsk (2006); Southey (2010 [1819]; Cortez (2009).

7 Até onde me foi dado conhecer, não há um estudo que contemple de modo aprofundado os aspectos militares do primeiro século da conquista. As informações e análises encontram-se dispersas numa bibliografia de certa amplitude, para qual remeto o leitor interessado: Frota (2000); (Southey (2010 [1819]); Varnhagen (1979 [1854]); Holanda (2007); Wehling (1994); e os cronistas coloniais. 
ortodoxia dramática como a dos espanhóis conquistadores de riquezas sem par fazendo uso de um exército célebre pela eficiência nascida da disciplina. A doutrina militar portuguesa marcadamente fluida e adaptável às diversas frentes e situações reais de combate com as quais se deparavam encontra nos tempos inicias da colonização e conquista uma imagem precisa: aventureiros, soldados da fortuna, nautas desgarrados, um punhado de empreendedores guerreando quase como senhores da guerra da Idade Média europeia.

A doutrina de combate da infantaria dos primeiros colonizadores - fluída e destituída de dogmatismos orgânicos - fundiu elementos já consagrados nas ofensivas realizadas nos continentes africano e asiático com traços bélicos dos combatentes locais. $\mathrm{O}$ grande fundamento operacional lusitano durante os tempos de ofensivas imperiais quinhentistas e quatrocentistas foi, sem sombra de dúvidas, a eleição de desembarques anfíbios como notável instrumento de projeção de poder militar intercontinental. Os ensinamentos obtidos com a larga utilização desse instrumento de combate incentivaram sua reutilização num novo palco de lutas. Nos espaços da América colonial portuguesa as contingências especificas de combate restringiram o uso de desembarques em larga escala. Estes foram utilizados, mas sob circunstâncias particulares e circunscritas. A intima ligação entre belonaves de ataque com poder de fogo concentrado e lançamento de tropas em solo teve restrita participação, tendo sido assinalada em pouquíssimas ações de luta, ao contrário do que aconteceu no oriente.

Uma dessas raras ações, que serve de modelo representativo de outras de igual dimensão - teve lugar nas terras de Vasco Fernandes Coutinho, a quem Gabriel Soares de Souza (200o [1587]) se refere como realizador de grandes feitos heroicos em terras do oriente. O quinhão que lhe coube foi aquele que posteriormente corresponderia ao estado do Espírito Santo. Território habitado por grupos humanos bem diferentes do pacifico modelo de guerreiro que recepcionou Nicolau Coelho no seu batel. Os Guaitacases foram decantados pelos textos cronistas como modelo de virtudes guerreiras. Quase espartanos no seu vigor e têmpera combativa que os distinguiam e os colocavam lado a lados dos ferocíssimos Aimorés, tidos como símbolo máximo da bruteza, ou ao menos assim os representam os cronistas quinhentistas. A cena de combate se integra a um dos episódios da saga de Vasco Fernandes Coutinho. Não está perfeitamente claro se ele teria tomado parte nessa ofensiva ou apenas atuou como comando de retaguarda:

E navegaram pelo dito rio arriba quatro dias, até que viram as cercas que estavam juntas da água, onde, pondo as proas em terra por estar maré cheia, por elas desembarcaram e saltaram fora os soldados, tornando-se os marinheiros com os navios ao meio do rio por não ficarem em seco na vazante, e os bombardeiros pera lá fazerem seus tiros. Começou-se a travar briga, na qual logo em primeiro encontro puseram o gentio em desbarate, mas, tornando-se a ajuntar e reformar, voltou com tanta força que forçou aos nossos a se desordenarem e misturarem com os inimigos, de 
maneira que os tiros que tiravam das embarcações não só os não defendiam, mas antes os feriam e matavam e, retirando-se pera se acolher a elas, estavam tanto ao pego que os mais foram a nado, e os feridos em algumas jangadas, entre os quais foram dois capitães Adorno e Morin, ficando o capitão mor com o seu alferes Joanne Monge na retaguarda, onde, crescendo o gentio que de outras aldeias vinham em socorro, os mataram às frechadas. (SALVADOR, 1975 [1627], p.153).

A ação descrita acima - como de resto, a maioria das outras de caráter anfíbio se deu num espaço liquido fluvial. Os rios e seus arrabaldes substituíram as praias como zona de desembarque porque na América, ao contrário do que se passou no oriente, estes se constituíam numa via de penetração para as áreas onde se desejava despejar homens de peleja. E nos anos de florescimento das capitanias isso se tornou ainda mais frequente porque os silvícolas - ou uma parte significativa deles - havia se retirado do litoral para interior fugindo da ação predatória dos invasores. É necessário destacar a simbiose homens-fogo presente no relato do combate. O desembarque se operou em moldes daqueles descritos nos livros da Índia - para usar uma das diletas expressões de Gabriel Soares de Souza -, canhonaço de artilharia embarcada - de menor poder, visto tratar-se de embarcações de reduzido tamanho. Dando cobertura a uma incursão ofensiva de uma infantaria indisciplinada arremetendo sobre um inimigo com um sistema de linha móvel de defesa e com uma retaguarda defensiva bem posicionada. Ao que tudo leva a crer, o método de confronto se assentava sobre a ação individual de luta que não se subordinava a princípios de organização coletiva.

Nem todas as situações de combate comportavam operações anfíbias, dadas a natureza do inimigo e das condições geográficas reinantes. Os aldeamentos - alvo primordial das incursões - localizavam-se em pontos variados, desde a proximidade da zona costeira ao interior inóspito do continente. Portanto, muitas tribos estavam posicionadas em pontos equidistantes dos corredores de tráfegos fluvial, o que impossibilitava deslocamentos ofensivos sobre cursos d'água. Dessa forma, as batalhas terrestres predominaram. Confrontos em zona aberta - em raras situações - ou pugnas demoradas em teatros de combate que dificultavam o deslocamento devido à natureza exuberante da selva tropical. "Como a guerra destas partes são nos matos, sempre vão enfiados por o ruim caminho uns atrás dos outros [...] como não podem ir em fileira nem ordem de guerra, ocupam muita terra ao cumprido" (SALVADOR, 1975 [1627]).

Confrontos em espaços de quase confinamento, o que limitava seriamente capacidade de manobrabilidade. O silvícola inimigo, senhor daqueles territórios por dilatado espaço de séculos, o conhecia perfeitamente bem e procurava adaptar sua doutrina de combate ao ambiente hostil. Dispersava suas forças, distribuindoas espraiadamente pelas cercanias. Colunas fixas, ao estilo de uma marcha em ordem unida, além de desconhecida para seu instrumental de luta, era também absolutamente inadequado para a situação real de luta imposta pelo meio paisagístico. 
Uma força que operasse de modo a adotar métodos padronizados de condução do confronto, facilmente sucumbiria frente a um adversário que interagisse com o ambiente de modo a tirar proveito dele como meio de defesa natural. Os portugueses tiraram rápido proveito desse ensinamento ao incorporar na sua doutrina de combate os métodos do inimigo. Se a maioria dos combates se deu, como parece indicar a documentação consultada, em espaços de escassa capacidade de execução de manobras, fazia-se necessário uma integração aos cânones militares lusitanos dos principais traços de luta dos adversários.

O sistema defensivo dos habitantes originais das terras invadidas tinha como seu principal fundamento uma arquitetura militar improvisada, um conjunto de cercas em linhas de profundidade. Elas eram conhecidas como caiçaras. Improvisadas, sem grande capacidade de resistir a canhonaços de artilharia móvel, mas que cumpriam sua função de anteparo de ações ofensivas de infantaria inimiga. O propósito inicial dessas edificações era a de resistir às incursões de tribos inimigas, ou seja, adversários dotados de tecnologia militar equivalente. A presença dos invasores europeus impôs a adoção de medidas de fortalecimento do instrumental de defesa e rechaço de ataques inesperados.

Nos relatos dos cronistas - Gabriel Soares de Souza, Frei Vicente e o Padre Simão de Vasconcelos - as ações militares portuguesas que se desenrolaram durante as décadas de vigência das capitanias demonstram que a condução da guerra na América portuguesa quinhentista se deu por adaptação de um aparato indígena. As ofensivas contra as aldeias situadas no interior, ou mesmo daquelas localizadas nas proximidades de grandes cursos d'água navegáveis, aconteceram com o uso de uma força de infantaria que se dividia em colunas móveis e autônomas e se lançava sobre o inimigo de forma desordenada. Isto é, do mesmo modo como ele combatia. As penetrações ofensivas - quando em circunstâncias de temor de superioridade numérica do grupo oponente - eram precedidas do soerguimento de uma cobertura de retaguarda sob forma das caiçaras instaladas em território hostil. As paliçadas defensivas - feitas de barro e madeira - balizavam a penetração em território adversário ao tempo que forneciam uma base de apoio fundamental para garantia de uma retirada ordeira em caso de desbaratamento. Funcionavam também como trincheira a partir da qual era possível repelir incursões das tribos alvo das operações de combate.

O relato de Frei Vicente é o que concede maior atenção aos aspectos militares da presença portuguesa na possessão colonial e nele podem ser facilmente encontradas referências aos métodos de luta dos invasores. ${ }^{8}$

Os de maior amplitude se desenrolaram nas cercanias da capitania de Pernambuco, tendo neles se sobressaído a figura de Duarte Coelho, tido como experimen-

\footnotetext{
8 Vide o livro terceiro e a primeira metade do livro quarto da obra de Frei Vicente de Salvador (1975 [1627]), com especial atenção para as páginas seguintes: 160; 163; 169-170; 188-190; 223-228; 239-240; $244^{-2} 45$.
} 
tado conhecedor das astúcias e artimanhas de combate dos silvícolas locais. Os cercos foram raros, tendo merecido destaque uma ação de sítio que teve lugar na vila de Igaraçu, fato que mereceu dos cronistas uma especial atenção. Via de regra, os habitantes originais da terra optavam, quando necessário, pelo estrangulamento das comunicações do perímetro da zona sitiada, numa tentativa de vencer o adversário pela fome. Os portugueses, por seu turno, penetravam impetuosamente em território hostil visando desalojar seus defensores por meio de uma vigorosa investida e do apoio do cerrado fogo de armas portáteis. Havendo dura reação por parte dos defensores, uma estrutura defensiva improvisada era erguida e servia como base a partir da qual subsequentes operações seriam levadas a termo até o completo extermínio dos infelizes responsáveis pela defesa de sua zona natural de habitação.

Os relatos de Frei Vicente podem ser confrontados com outras fontes mais antigas como a narrativa testemunhal de um membro de um desses confrontos. Há muitos pontos convergentes que juntos permitem uma visualização da doutrina militar portuguesa posta à serviço da conquista colonial. Todos os cronistas consultados, bem como os relatos avulsos de natureza outra que não cronistica, concordam que o sistema ofensivo primava pela improvisação tática. "Cada um era capitão de si mesmo" (SALVADOR, 1975 [1627], p.116), como nos aponta o clérigo português. Sem um sistema de organização militar preciso e sem regras de combate perfeitamente delineadas numa campanha de longa duração, o que disso resultava concretamente era a adoção de padrões de conduta de guerreiros de sociedades ditas primitivas. O mercenário alemão Hans Staden testemunhou o cerco de Igaraçu que teve lugar na capitania de Pernambuco. O relato que dele nos deixou contempla o sistema tático de combate dos portugueses na América da segunda metade do quinhentismo. Note-se que outros cronistas se referem ao mesmo combate com certa riqueza de detalhes, mas nada que supere a narrativa do soldado germânico:

Rebentou então, por culpa dos portugueses, uma revolta dos índios [...] E o chefe da terra pediu-nos pelo amor de Deus, que fossemos à pressa auxiliar o lugar Igaraçu. [...] O lugar onde estávamos situados era rodeado de mata. Nesta haviam disposto os selvagens duas fortificações com ajuda de grossos troncos de árvores. Aí se recolhiam durante a noite e esperavam pelas nossas sortidas. De dia permaneciam nas valas, que haviam cavado ao redor da povoação, das quais saiam para escaramuças. Quando lhes atirávamos, estendiam-se no chão, para escapar às balas. Assim sitiaramnos de tal modo que, donde estávamos, ninguém podia entrar ou sair. [...] Aproximaram-se da povoação, lançaram ao ar grande quantidade de flechas, que deviam atingir-nos quando caíssem, utilizando também muitas delas às quais haviam amarrado mechas de algodão embebido em cêra. Com estas flechas acesas pretendiam atear fogo ao teto das choças. Ameaçavam também devorar-nos, se nos pudessem capturar (STADEN, 1974 [1557], p .47). 
No cerco de Igaraçu defensores e atacantes recorreram a métodos de combate estranhos aos seus respectivos universos de luta armada. Uma simbiose adaptativa que fincou raízes mais profundas no sistema ofensivo português. Estes - os invasores - com rapidez se aperceberam da premente necessidade de defesas fixas em solo para fazer frente a um adversário que confiava quase que unicamente na mobilidade absoluta de guerreiros individualistas. A investidura impetuosa em território hostil reclamava uma linha de retaguarda materializada nos caiçaras. O testemunho de Hans Staden nos afiança que as ações expedicionárias se faziam apoiadas por casamatas improvisadas que conseguiam comprometer a capacidade de deslocamento inimigo. Os habitantes originais da terra, por seu turno, também recorreram a adaptações, dentre as quais cumpre destacar o uso de trincheiras escavadas em solo, indispensável instrumental de defesa contra o pesado fogo de artilharia portátil dos sitiados.

Portanto, defesa e ataque funcionavam em híbrido sistema que conjugava assimilações que não modificavam a essência dos respectivos modus operandi militar que, de resto, eram muito aparentados entre si. O sistema de capitanias delegava aos donatários poderes de senhores da guerra locais, o que implicava, como enfatiza queixosamente Duarte Coelho numa das cartas que dirigiu ao monarca português, em "[...] fazerem-na [a guerra] eles [os donatários] como melhor lhes parecer e a necessidade se lhes oferecer" (Coelho, 1997 [1546], p. 102). Inexistindo um sistema militar organizado nos moldes daquele do Estado português na Índia, o comando se encontrava delegado a organizadores de ações táticas, sendo que muitas delas motivadas por interesses de pilhagem particular. ${ }^{9}$

Cada um dos centros semi-isolados de presença de colonos lusitanos funcionava com um senso de autonomia marcial quase ao estilo de uma estrutura ofensiva desconectado de uma concepção estratégica ampla.

O modelo quase arquetípico dessa concepção de organização militar é Duarte Coelho, decantado por Frei Vicente, pelo padre Simão de Vasconcelos e mesmo por Gabriel Soares de Souza que concede comedida atenção às ações de combate dos donatários ou de quaisquer outros colonos. No texto de História do Brasil (1975 [1627]] o clérigo português evidencia que a doação da capitania de Pernambuco resultou diretamente dos muitos serviços prestados pelo donatário nas guerras da Índia nas quais teve destacada participação. Esse destemido combatente é personagem central de cerca 5 ou 6 capítulos da crônica, sempre presente como comandante militar tático à frente de ofensivas de desbaratamento do poderio indígena nas cercanias de suas terras ou de seus vizinhos donatários. É quase uma saga cavaleiresca na qual toma parte não apenas Coelho, mas também seus companheiros de demandas aventurosas, cujos nomes também nos foram dados a conhecer, incluindo seus dois filhos que encontraram morte trágica numa mesma semana.

\footnotetext{
9 As cartas de Duarte Coelho disso oferecem um eloquente e detalhado testemunho.
} 
Duarte Coelho ocupa nas crônicas quinhentistas posição equivalente a do infante Dom Henrique nos textos da cronistica quatrocentista de Gomes Eanes de Zurara: é modelo acabado de virtudes militares épicas. Retomam os narradores das obras que citam seus feitos aos moldes da construção narrativa das gestas cavaleirescas. Nas cartas que enviou ao rei Dom João III nota o leitor que talvez a representação heroica feita pelos cronistas não esteja tão contaminada por intenções panegiricas como a princípio possa parecer. Nota-se que se trata de um soldado experimentado e prudente, inimigo de ações desarrazoadas contra os habitantes originais da terra. Apesar de tencionar - como todos os demais - a ocupação e exploração econômica das terras em posse dos silvícolas, tinha ciência da precariedade do sistema de defesa erguido pelos invasores, daí porque a premente necessidade de manutenção da cautela.

Comedido, mas nem por isso menos disposto a executar ações ofensivas para desalojar os inimigos encastelados no interior da nova possessão colonial lusitana. Dentre os capítulos, por assim dizer, militares da crônica de Frei Vicente, os de maior extensão relatam incursões ou situações de defesa ou sítio protagonizadas por Duarte Coelho. O sistema bélico a seu dispor era constituído pelas bocas de fogo mobilizáveis nas circunscrições próximas e que poderiam ser acrescidas - e frequentemente eram - de aliados locais, grupos indígenas com os quais se estabeleceram relações comerciais e políticas de aliança diplomática informal. Diferentemente do que acontecia na Índia, por se tratar de grupos isolados, não haviam grandes belonaves fundeadas no litoral próximo e prontas a desfechar uma borrasca de fogo e chumbo quente sobre as formações móveis inimigas. $\mathrm{O}$ apoio de artilharia se constituía de artefatos menores facilmente transportáveis - falcões e berços - e de alcance médio, mas de eficácia contra um adversário inteiramente destituído de armas de arremesso balístico.

Essa força armada - que pode ser tomada como retrato três por quatro, em preto e branco das demais ações organizadas em outras capitanias ou mesmo em tempos anteriores a elas - quando seu uso se fazia necessário, se deslocava por via fluvial ou terrestre, sempre tendo em mira surpreender o inimigo e vencer sua superioridade numérica. Eram ações incursoras de raio de alcance limitado - em se tratando de deslocamentos a pé - que não intencionavam de imediato ocupação territorial por impossibilidade de executar tal meta, dada a insuficiência de meios. Um sistema baseado em avanços e ataques seguidos de recuos para recomposição do esforço ofensivo destituído de um necessário grau de autonomia. A guerra como nos ensina Clausewitz (2010 [1832]) - nunca é a ação de uma massa ativa sobre outra passiva, sendo, ao contrário, o choque de duas forças ativas. Razão pela qual não seria lógico esperar que os habitantes originais das terras permanecessem no interior de suas posições aguardando serem massacrados. As reações se faziam sob forma de vigorosas investidas contra todos os pontos de habitação dos invasores, incidindo suas operações sobre áreas desguarnecidas ou de armazenamento de víveres indispensáveis à manutenção da existência, fisicamente falando. 
Quando operando por penetração no interior através de vias fluviais, os combatentes sob ordens de Duarte Coelho e seus filhos - Jorge de Albuquerque e Duarte de Albuquerque - realizavam desembarques anfíbios de escala limitada, seguidos de marchas de aproximação do território alvo. Uma precária base de retaguarda era erguida - segundo Frei Vicente (1975 [1627]), constituída de cabanas improvisadas que imitavam o modelo indígena e que recebem do cronista o título de Tijupares - e junto dela edificavam um sistema de defesa ao estilo de um forte primitivo. Em alguns casos - vide as operações nas cercanias das vilas de Cananéia e São Vicente - o intervalo de tempo da intervenção armada se estendia por mais de um ano. Neste último, devem ser incluídas apenas ofensivas contra localidades que possuíam uma rede de aldeamentos populosos, o que reclamava persistência até a completa execução do esperado extermínio do inimigo e a consequente apropriação de seus recursos materiais.

Não deve ser esquecido um outro aspecto militar de certa relevância para a discussão aqui estabelecida: as Entradas, ${ }^{10}$ ou expedições exploratórias ao interior em demanda de riquezas minerais e peia de escravos, também seduziu Duarte Coelho. Este é um dos temas recorrentes na correspondência trocada com o monarca português. Mais que isso, era um assunto que se constituía numa de suas grandes preocupações como responsável pela autoridade nas cercanias do centro de povoamento lusitano denominado capitania de Pernambuco. As motivações que ela deixa transparecer - além das óbvias emulações por ganhos pecuniários - se situam num plano de busca pela realização de ações heroicas potencialmente capazes de conceder renome ao seu realizador. A mentalidade cavaleiresca que preside as ações de combate nos aspectos táticos e estratégicos e que também se mostram presente na dilatação do espaço geográfico colonial, muitas vezes conseguido à custa de expedições motivadas por fatores de preponderância simbólica. O mito foi também fator de expansão geográfica, como disso podem atestar as prolongadas demandas por lagoas fabulosas, montanhas de prata, minas de metais no interior na Bahia ${ }^{11}$ ou um reino fabuloso cujo senhor era "Rei Branco" (Southey (2010 [1819]). Um imaginário mítico-fabuloso de fundamentação livresca e - em alguns casos - extraído de referências do universo literário das sagas de novelas de cavalaria medieval, nas quais, como é de conhecimento amplo, o maravilhoso ocupa privilegiado espaço.

A conquista da região ao redor do rio da Paraíba resultou em prolongada campanha militar com desdobramentos variados. Uma das expedições enviadas para

10 Sobre esse tema consultar Taunay (1975). Recorde-se que Gabriel Soares de Souza perdeu sua vida numa dessas incursões exploratórias rumo ao interior da Bahia quinhentista.

${ }^{11} \mathrm{O}$ mito da existência de riquezas minerais fabulosas no interior da Bahia é um dos mais persistentes no imaginário popular desde o início da conquista militar colonial. Das lagoas míticas de onde brotavam diamantes, passando pelas montanhas e minas de prata e concluindo com as misteriosas ruínas de uma imensa cidade pré-colombiana de origem desconhecida na região da Serra do Sincorá. Os ecos dessas narrativas persistiram até meados do século XX. Acerca disso veja-se Holanda (2007). 
essa região a fim de aniquilar a resistência dos habitantes locais teve por líder um certo Pedro Lopes - acerca de quem muito pouco sabemos, visto que as crônicas sobre ele quase nada dizem, ao que parece um veterano de combates no oriente. Ele teria organizado uma incursão com o intuito de desbaratar um grupo de inimigos encastelados na região de Tamaracá. A força se dividiu em três colunas móveis e independentes entre si - o mesmo modelo já conhecido das descrições dos cronistas da Índia - incorrendo como pinças sobre a área alvo. Os habitantes originais da terra ergueram - como já esperado - uma paliçada defensiva atrás da qual se recolheram e de onde fustigavam o adversário. O método de ataque dos portugueses foi o de ofensa direta, desorganizada e heroica:

E, vindo por diante, discorrendo a uma parte e a outra, toparam os nossos corredores com uma cerca muito grande e forte por uma parte. [...] Pedro Lopes que andava já tão versado nestas guerras, depois de os exortar e animar com muitas razões toda a noite, o dia seguinte pela manhã os repartiu em três esquadrões iguais e mandou marchar à vista da cerca, donde, vendo o vagar e temor com que iam, se adiantou e, embraçando a adarga e a espada na mão, se partiu pera a cerca dizendo "siga-me quem quiser, e quem não quiser fique, que eu só basto”. (SALVADOR, 1975 [1627], p. 259).

Fica patente que os métodos de combate dos dois lados envolvidos na contenda pela posse das terras são aparentados entre si. Ambos - invasores e defensores do território - partilham de uma mentalidade militar de guerreiros de sociedades ditas primitivas e fazem uso dela com variações derivadas de contexto cultural e tecnológico. Claro está que os portugueses possuíam evidente superioridade tecnológica, o que permitia a eles ditar os rumos da contenda: via de regra, escolhiam a hora e local das lutas, com algumas exceções. O modus operandi comum aos dois grupos rivais privilegiava a ofensiva cega e destituída de prévias considerações organizacionais no plano tático. Se Pedro Lopes se lançou em fúria rumo ao alvo a ser debelado, as fortificações atrás da qual o inimigo se escondia, era porque confiava em dois elementos vitais que não devem ser desmerecidos: a possessão quase demoníaca de um Aquiles e na expectativa de ganhos imateriais decorrentes de uma exposição pública de heroísmo guerreiro. Portanto, a correria à moda árabe foi o grande elemento tático das ofensivas contra as aldeias indígenas. E na América portuguesa esse padrão se fazia ainda mais necessário tendo em vista a ausência de cobertura de artilharia de retaguarda, peça fundamental de uma ofensiva sistemática.

O modelo de incentivo pelo exemplo de coragem é patrimônio de uma cultura militar cujo desenvolvimento se deu à margem daquilo que se convencionou denominar de modo ocidental de guerrear. Em sociedades que elegem a guerra não como fator instrumental de relações entre grupos humanos rivais, mas, sim, como algo que se fecha sobre si mesmo, o guerreiro ocupa posição social privilegiada advinda de feitos marciais praticados. Conhecido é o estudo de Pierre Clastres (1984) a respeito da função da guerra nas sociedades ditas primitivas e nele teorizações 
sobre o tema tratado podem ser encontradas. Pedro Lopes conjuga no seu arroubo guerreiro imagens extraídas de um imaginário cavaleiresco com outras de procedência cultural distintas, mais intimamente associadas com uma postura em combate que crê na manifestação de exemplo heroico como uma virtude militar indispensável. O inimigo a ser por ele combatido, o silvícola, alimentava-se de expectativas similares. Desdenhavam ambos de sistemas de organização que fizessem o combatente tornar-se peça anônima de uma engrenagem. O renome obtido apenas por ação individual distintiva importava mais do que considerações em torno da segurança pessoal do combatente.

O último marco cronológico da presença militar portuguesa na possessão ultramarina a ser aqui considerado é o da instalação de um regime de centralização das decisões de comando administrativo e de combate. A primeira tentativa de ocupação definitiva organizada com o sistema de capitanias hereditárias, não lograria obter o almejado lucro advindo da exploração econômica das terras e de suas possíveis riquezas minerais. Quase todas malograram devido a rivalidades, desorganização e reações armadas por parte dos ocupantes originais das terras, que reagiram à tentativa de escravização e rapinagem levada a termo pelos europeus. A capitania do donatário Francisco Pereira Coutinho, localizada em terras que hoje formam o Estado da Bahia, foi a que mais represálias sofreu por parte dos silvícolas, que destruíram quase inteiramente a precária estrutura urbana erguida pelos europeus na Baía de Todos os Santos, a denominada Vila do Pereira.

Em 1549, três naus (a Nossa Senhora da Conceição, a Salvador e a Nossa Senhora da Ajuda) duas caravelas (Leoa e Baia) e um bergantim (São Roque), compuseram a frota de invasão portuguesa à Baía de Todos os Santos. Trazia ela, de acordo com a observação feita por Gabriel Soares de Souza (2000 [1585]) - narrador minucioso e atento dos primórdios da Bahia, que Gilberto Freyre (2000) não hesita em defini-lo como um quase bisbilhoteiro -, 6oo homens de armas, marinheiros, padre da companhia de Jesus, liderados por Manoel da Nóbrega e 400 degredados a quem caberia a tarefa de colonizar as terras tomadas de assalto à população local. Cabia o comando a Tomé de Souza, veterano da Ásia, onde, segundo consta, destacada foi sua participação no comando das tropas lusitanas que atuaram no subcontinente indiano. ${ }^{12}$

Os portugueses, cumprindo instruções escritas, o chamado regimento dos governadores, estabeleceram uma cabeça-de-ponte na região do atual forte de São Diogo, ao norte do Farol da Barra. Naquele sítio foi erguida a cidade-fortaleza de Salvador, que exerceria uma dupla missão: administrativa, como sede da autoridade máxima das tropas invasoras que ocupavam o território sob controle do inimigo;

\footnotetext{
${ }^{12}$ Sobre expedição de Tomé de Souza e seu desembarque seguido da fundação da cidade-fortaleza de Salvador há uma copiosa bibliografia. As informações utilizadas para construção ensaística das interpretações que seguem as consultei acessando um conjunto de obras tidas como referências sobre o tema. Ao leitor interessado remeto ao estudo de Sampaio (1949); Carneiro (1985); Azevedo (1968); Tavares (2011); Risério (2000).
} 
e militar, atuando como baluarte defensivo contra operações marítimas por parte de adversários de precedência europeia, e como ponto de apoio a operações terrestres ofensivas de penetração para o interior, visando alargar a estreita cabeçade-ponte, desalojando os inimigos nativos da região e ocupando suas terras que, a partir de então, seriam doadas como recompensa (por participação nos combates) aos principais capitães para fins de ocupação e colonização. Vide, a título de ilustração, o sesmeiro Gárcia D'ávila, senhor da Casa da Torre.

A expansão territorial dos núcleos populacionais a partir da estreita cabeça-deponte portuguesa foi essencialmente baseada em ações militares. As terras em derredor da Baía de Todos os Santos, o chamado recôncavo baiano, estavam em poder das populações indígenas. Os invasores procuraram desalojá-los por meio de campanhas sistemáticas de extermínio e recolha de prisioneiros para atuarem como mão-de-obra escrava. Um cronista seiscentista (VAsconcELOS, 1977 [1663]) estima que em uma única incursão 300 aldeias inimigas estabelecidas nas cercanias da cidade de Salvador teriam sido extintas a ferro e fogo na segunda metade do século XVI, números certamente inflados, talvez por dificuldades de acesso a fontes de informação confiáveis à época da redação do texto.

Os combates travados entre as forças invasoras recém-desembarcadas e os defensores em terra (senhores originais do território em disputa) foram desiguais, sangrentos e de prolongada duração. Estendendo-se por um longo período, os séculos da conquista, do alargamento da cabeça-de-ponte lusitana, da penetração para o interior do continente a ser conquistado. O primeiro núcleo povoador e que também serviu como praça-forte e ponto de apoio logístico para incursões predatórias ao território inimigo foi a chamada vila do Pereira, fundada pelo donatário Francisco Pereira Coutinho, instalada na região do atual Farol da Barra, em Salvador. Nesta praça-forte (e pequena vila), foram desencadeados os primeiros combates dos tempos iniciais da colonização. Por volta de 1545, os invasores sofreram o primeiro contragolpe. Atiçados por franceses, tribos Tupinambás aldeadas ao redor da Baía de Todos os Santos atacaram com eficiência, impingindo danos irreparáveis à estrutura defensiva inimiga. A vila do Pereira foi completamente arrasada, seu comandante, Francisco Pereira Coutinho, feito prisioneiro e ritualisticamente devorado pelos Tupinambás. Outras incursões predatórias seriam levadas a termo nas duas outras zonas de presença lusitana nas terras da Bahia, tendo produzido resultados similares.

Esses contínuos ataques destrutivos por parte dos defensores das terras, objeto de conquista europeia, levaram os portugueses à adoção de uma estratégia mais agressiva de combates às forças inimigas. A grande batalha de caça e extermínio (ao melhor estilo da doutrina do estado-maior geral do exército norte-americano durante a guerra do Vietnã) aconteceria durante o período de comando do representante militar da autoridade civil invasora, o segundo governador, D. Duarte da Costa. Por volta de maio de 1555, um grande levante de tribos indígenas colocou sob ameaça a existência da estreita cabeça-de-ponte das forças invasoras. Um 
grande ataque Tupinambá foi desencadeado, porém rapidamente contido. Após absorverem o golpe, os portugueses contra-atacaram liderados pelo próprio governador e seu filho, Álvaro da Costa. Todas as aldeias em redor da Baía de Todos os Santos foram sistematicamente exterminadas. Adotando os mesmos padrões operacionais dos marines, no Vietnã. A expedição punitiva estendeu-se às aldeias situadas nas proximidades do Recôncavo, todas sistematicamente massacradas.

Na cidade da Bahia andava neste tempo ocupado o governador Dom Duarte da Costa em guerras com todos os índios. E a ocasião foi o levantamento de alguns principais descontentes. Eram poderosos em arcos, e sofriam mal a soberania dos portugueses, que cada dia entravam pela terra dentro com suas fazendas, e iam fazendo-se senhores até o sertão. E como era gente valente a dos tupinambás, [...] confederados com os tapuias [...] levantaram-se, e pondo-se em armas, fizeram assaltos em diversas partes, matando, e roubando nelas, e pelos caminhos tudo quanto achavam, com confusão desordenada dos moradores todos. [...] Fez-se enfim a guerra; porém com tal prudência, que se visse o intento de castigar, e não pudesse ver-se perigo de sermos vencidos. Montou muito para este efeito a boa indústria do capitão Álvaro da Costa (VASCONCELOS, 1977 [1663], p.12).

A crônica do padre Simão de Vasconcelos - da qual nos valeremos a partir daqui - apesar de ampla, lamentavelmente oferece limitadas informações sobre a situação militar da colônia no período quinhentista. As referências aos conflitos são poucas - embora de substancial interesse - e basicamente se concentram em dois momentos: o das façanhas de Duarte Coelho, figura que parece ter incendiado o imaginário dos cronistas, e os combates travados após a implementação do sistema de centralização administrativa após chegada de Tomé de Souza. O clérigo, como ele deixa claramente evidenciado em várias passagens de seu texto, sente pouco entusiasmo pela narrativa de feitos de armas, razão pela qual decide assinalar apenas os mais contundentes, ou os que ele assim considerou. A melhor descrição é aquela associada às guerras de Mem de Sá e Duarte da Costa contra os índios Aimorés, ${ }^{13}$ por via delas podemos ter acesso aos fundamentos da mentalidade militar que animava as ações de combate lusitanas durante o período da centralização administrativa na Terra de Santa Cruz, ou do pau-de-tinta, como a denomina com peculiar vocabulário o Frei Vicente de Salvador:

Estes Aimorés pois, selvagens, e agrestes, por estes tempos começaram a descer de suas serras, em que viviam havia tantos anos: e guiados das

13 Sobre os índios Aimorés ou Botocudos, louvados e temidos por todos os cronistas quinhentistas, há uma substancial gama de informações extraídas de observação direta de muitos observadores europeus dos tempos iniciais da colônia. Veja-se as minuciosas observações de Gabriel Soares de Souza; as divertidas notas de Frei Vicente de Salvador; o Padre Simão de Vasconcelos. Para estudos recentes veja-se o clássico e volumoso História dos índios no Brasil, organizado por Manuela Carneiro da Cunha (1992). Há um capítulo inteiro dedicado a esta belicosa etnia. É indispensável ainda a consulta a John Hemming (2007) por apresentar um certo viés militar das ações de conquista das terras dos silvícolas nacionais. 
correntes dos rios, vinham após eles sair ao mar, e davam assaltos em tudo o que achavam, matando e assolando os escravos, e fazendas dos moradores. [...] O governador Mem de Sá [..] fosse em pessoa acudir a insolência daqueles bárbaros, por honra de Deus, e do nome das armas de Portugal. Ajuntou navios ligeiros, escolheu soldados de satisfação, e alguns índios das aldeias, e desembarcou, em breve tempo, no porto de Ilhéus. [...] Saíram das brenhas de improviso [os Aimorés], quais ursos assanhados, a quem os caçadores mataram os filhos. [...] O experimentado capitão [português], prevendo o caso, tinha deixado emboscado no mato contrafilado, com ordem que ouvindo sinal acudisse. [...] Fingiram os nossos que se retiravam, apressando o passo. [...] Sentiram eles [os índios] os arcabuzes e sobre as cabeças as espadas dos portugueses. [...] Saiu-lhes ao encontro [Mem de Sá] (levando ao diante como costumava, o vivífico estandarte da cruz) e acometendo a cavalo armado o meio de seu esquadrão, ficaram atônitos os bárbaros, que nunca viram tal modo de pelejar; desorganizaram-se e começaram a sentir o rigor da arcabuzaria, que por parte da terra e do mar os cercava e fazia matança cruel. Mem de Sá animou os soldados e mandou que arremetessem a todo poder e perigo por todas as partes. [...] E em breve espaço se viram as praias cobertas de corpos sem alma e as espumas do mar tornadas cor de sangue. (VASCONCELOS, 1977, [1667] p.57-58).

Do exposto acima e na citação anterior alguns aspectos podem ser evidenciados. Primeiro, o sistema de organização militar pós regime de capitanias apresenta um certo padrão de ordenamento. A partir dos indícios disponíveis não é possível afirmar se as forças envolvidas nos combates em solo são integrantes de um exército de profissionais, contudo, pode-se facilmente deduzir que já não são uma milícia de colonos. Sabe-se que que quando de seu desembarque na Baia de Todos os Santos, Tomé de Souza trouxe consigo soldados pagos regularmente, o que indicaria uma organização marcial formal em vias de construção (CARNEIRO, 1985). Os guerreiros de Mem de Sá e Duarte da Costa não se assemelham aos que acompanhavam Duarte Coelho em suas incursões pelo interior do continente visando desalojar os aldeamentos indígenas. Em termos de uma condução tática da ofensiva, os portugueses mostram que seu sistema de combate primava pela fluidez e adaptação aos cânones locais de luta. Dos inimigos aprenderam a fazer uso de recursos ao estilo de ardis, como fica evidente na manobra feita por Mem de Sá para vencer os Aimorés.

O princípio tático dominante nas incursões da infantaria portuguesa em quase todas as incursões descritas nos textos dos cronistas foi o das razzias. Ou seja, operações de penetração funda e rápida em território inimigo. Confiantes na mobilidade como vetor de superação das linhas adversárias, os infantes se organizavam em grupos semiautônomos de combate que se deslocavam constantemente fornecendo apoio mútuo - e não necessariamente organizado - entre si. É de uma quase frente fluida que estamos tratando. A mobilidade era tão acentuada que resvalava para um sistema de front diluído. A infantaria se comportava como uma força 
móvel dotada da mesma possiblidade de deslocamento de uma cavalaria. Uma herança cultural da presença árabe na península Ibérica.

Em termos de condução tática da infantaria, a arma militar terrestre portuguesa adotou como princípio norteador de suas ações a postura organizacional de uma força de intervenção rápida que se atinha essencialmente ao desmantelamento do dispositivo tático ofensivo inimigo. Fogo e manobras não tinham por metas finais - conforme seria esperado de uma armada moderna - a ocupação de território sobre controle do inimigo. Não se integrava à mentalidade ofensiva lusitana a ocupação clássica de terreno com expulsão de adversário e confisco de sua "zona de matança”. Por centrar suas ações na mobilidade, o ataque e desbaratamento não era seguido obrigatoriamente de fixações de bases que balizassem avanço e servissem de ponto de apoio para penetrações posteriores território adentro. Sem intenções de presença permanente em solo hostil e estando desprovido de meios ofensivos que permitissem pacificar em definitivo as áreas temporariamente ocupadas, a movimentação tática absoluta era o grande paradigma das operações ofensivas realizadas nos três continentes alvo das incursões imperiais.

Ataque, força e movimento contínuo seguido de avanços e recuos de natureza tática ou de simples manobra diversionista. Em verdade a doutrina militar portuguesa da expansão imperial se concentrou muito mais em mobilidade do que em manobras ou fogo de armas portáteis. O choque direto e a ruptura das linhas inimigas por aplicação incisiva da força se adequavam mais perfeitamente com a mentalidade cavaleiresca que presidia as ações de luta em solo. Nas crônicas quatrocentistas ou quinhentistas escassas são as referências ao uso de manobras em larga como componente tático essencial. Manobrar a força de ataque por meio de ardis não contribuiu para nenhuma das vitórias significativas da expansão imperial seja na Ásia, na África ou na América portuguesa.

O exército português que combateu ao longo dos dois primeiros séculos da expansão imperial submeteu povos e levou a ruína e morte em larga escala para inúmeras populações atuando sempre como uma cavalaria do mar. Como cavaleiros - o termo aqui sendo utilizado na acepção de combatente que faz uso dos métodos de guerreiros que confiam unicamente na força individual - lutaram e pereceram em praias hostis, junto a muralhas de cidadelas ou no interior de densas áreas fechadas de selva tropical. O termo cavalaria não implica na adoção de um código de conduta elevado que faria desses combatentes guerreiros humanizados, como aqueles que assistimos nas novelas da tradição cavaleiresca. A adoção de posturas de combate, por assim dizer, pré-civilizacionais, não implicou numa reprodução de regras de luta rígidas que delimitassem e contivessem a violência. A guerra levada a termos pelos nautas portugueses foi tão dura e desapiedada quanto qualquer outra, nada ficando a dever ao que era posto em ação pelos seus inimigos.

Nem modernos nem decisivamente utilitaristas. Primaram os portugueses pelo uso de táticas de confronto ainda subordinadas ao ritualístico em detrimento dos aspectos práticos do uso da agressão para fins de hegemonia sobre o adversário. 
$\mathrm{Na}$ América portuguesa esse elemento pode ter interferido menos do que nas incursões no oriente, mas seu valor não deve ser desconsiderado. Uma grande variante com relação aos modelos já consagrados nas campanhas quatrocentistas em solo africano e quinhentista no oriente, não há. A formulação de combate da expansão imperial portuguesa foi em sua essência a mesma, tendo permanecido quase que inalterada desde até o fim do século XVI. Apesar das inovações táticas e da adoção de novos armamentos que marcaram a arte de guerrear na Europa durante o período da expansão imperial, essas modificações não se fazem notar nos relatos das crônicas ou nas cartas escritas por participantes dos confrontos ou clérigos que deles teriam tomado conhecimento por via indireta.

\section{Referências}

Albugueroue, Luís de. Navegadores, Viajantes e Aventureiros Portugueses, Séculos XV e XVI. Lisboa: editorial Caminho, 1992.

Azevedo, Thales de. Povoamento da Cidade de Salvador. Salvador: Prefeitura Municipal de Salvador, 1968. 1949.

Bernard, Carmen. Gruzinski, Serge. História do Novo Mundo. São Paulo: Edusp, 2001.

Campos, João da Silva. Crônica da Capitania de São forge dos Ilhéus. Ilhéus: Editus, 2006.

Caminha, Pero Vaz de. Carta a el rey Dom Manuel. Rio de Janeiro: Ediouro, 2000

Cardim, Fernão. Tratado da Terra e Gente do Brasil. São Paulo: Cia. Da Editora Nacional, 1939.

CARneiro, Edson. A Cidade de Salvador (1549) uma reconstituição histórica. São Paulo: civilização brasileira, 1985 .

Clastres, Pierre. Arqueologia da violência. Ensaios de antropologia política. Brasiliense: São Paulo, 1984.

Clausewitz, Carl Von. Da Guerra. São Paulo: Martins Fontes, 2010.

Coelho, Duarte. Cartas a El Rei. Recife: Massangana, 1997.

Cortesão, Jaime. Os Descobrimentos Portugueses. Lisboa: Edições 70, 1992

Cortez, Hernán. A conquista do México. Porto Alegre: LPM editores, 2009

Frota, Guilherme de Andrea. Quinhentos anos de História do Brasil. Rio de Janeiro: Biblioteca do Exército, 2000.

Freyre, Gilberto. Casa Grande e Senzala. São Paulo: Global, zooo.

Gandavo, Pero de Magalhães. História da Província de Santa Cruz: tratado da terra do Brasil. São Paulo: Obelisco, 1964. 
Godinho, Vitorino Magalhães. Mito e Mercadoria, Utopia e prática de navegar. Séculos XII-XVIII. Lisboa: Difel, 1990.

Hemming, John. Ouro vermelho: a conquista dos índios brasileiros. São Paulo: Edusp, 2007.

Holanda, Sérgio Buarque de. Visão do paraíso: os motivos edênicos no descobrimento e colonização do Brasil. 6a . Ed., São Paulo: Brasiliense, 2007.

Peres, Damião. História Dos Descobrimentos Portugueses. Porto: vertente, 1992.

Risério, Antônio. Uma história da cidade da Bahia. Rio de Janeiro: Versal, 2000.

Sampaio, Teodoro. Fundação da Cidade de Salvador. Salvador: Typographia Beneditina, 1949 .

Salvador, Frei Vicente de. História do Brasil. São Paulo: Melhoramentos, 1979.

Southey, Robert. História do Brasil. Brasília: Edições do Senado Federal, 2010.

SouzA, Gabriel Soares de. Tratado Descritivo do Brasil. Recife: Fundação Joaquim Nabuco, 2000.

Staden, Hans. Duas viagens ao Brasil. Itatiaia: Belo Horizonte, 1974.

Taunay, Afonso E. História das Bandeiras Paulistas. São Paulo: Melhoramentos, 1975 .

Tavares, Luís Henrique Dias. História da Bahia. São Paulo: Unesp, 2011.

Varnhagen, Francisco Adolfo. História geral do Brasil: antes de sua separação e independência de Portugal. São Paulo: Melhoramentos, 1979.

Vasconcelos, Simão de. Crónica da Companhia de Jesus. Rio de Janeiro: Instituto Nacional do Livro, 1977.

Wehling, Arno. Formação do Brasil Colonial. Rio de Janeiro: Nova Fronteira, 1994.

Recebido em 27 de janeiro de 2021.

Aprovado em 15 de junho de 2021.

\section{Resumo}

A doutrina de combate da expansão imperial na cronística portuguesa da Terra de Santa Cruz

\section{Wellington José Gomes Freire}

O presente artigo pretende se deter sobre a representação dos modos de condução da guerra da expansão imperial portuguesa quinhentista contida nas narrativas cronisticas que tratam da presença militar lusitana na América portuguesa. 
Pleiteia-se que os métodos de combate descritos nos textos sugerem que a revolução nos assuntos militares, termo que designa na bibliografia especializada o processo de modernização dos exércitos europeus modernos, não fincou raízes em solo lusitano quatrocentista e quinhentista. Os guerreiros e conquistadores que se assenhorearam de uma vasta porção do globo utilizaram predominantemente de táticas de incursão de infantaria desordenada ao estilo de razias. O estudo se baseou em um corpus constituído por cronistas quatrocentistas e quinhentistas: Gomes Eanes de Zurara; Rui de Pina; João de Barros; Lopes de Castanheda; Gaspar Correia; Gabriel Soares de Souza e Frei Vicente de Salvador.

Palavras-chave: expansão marítima portuguesa, guerra, narrativas de cavalaria. 